\title{
Editorial Vol.73 (1) March 2020
}

\section{Anandaraj ${ }^{1}$}

C Indian Phytopathological Society 2020
The first issue, volume 73 of Indian Phytopathology, for January-March 2020 is ready. In this issue, there are 20 articles including two review articles, 14 research articles, three short communications and one new report.

The review article by Dr. M.S. Saharan highlighted the status of resistant source to Fusarium head blight (FHB) disease. The information available on resistant sources in wheat and its wild relatives have been reviewed, so that breeders can use suitable sources to incorporate resistance in adopted cultivars of wheat against FHB disease. Another review article on "Biological control of Fusarium wilt in crop plants using non-pathogenic isolates of Fusarium species" by Suresh Patil and S. Sriram has given a summary of different reports of non-pathogenic Fusarium in diverse cropping systems with special reference to their mode of action (antibiosis, plant growth promotion and induced systemic resistance), molecular basis of bioassay and identification, environmental conditions, different formulations, cross protection as well as effects on non-target crops. Two articles on bacteriology discussed the bioactivity potential of endophytic fungi and rhizobacteria while third article narrated the host defense induction in grape vines by the strains of Bacillus against powdery mildew. Mark Angelo Balendres proved the role of Colletotrichum musae in the susceptibility of banana to post harvest anthracnose disease. The articles on efficacy of silver nanoparticles and phylloplane yeasts have provided scope in better and eco-friendly management of pathogenic fungi. Bahaderjeet Singh has established a correlation between weather parameters, sowing dates and Alternaria blight development in rapeseed. The citrus tristeza virus has been addressed in two articles focusing on coat protein based characterization and analysis of recombination among the isolates available in the north-eastern parts of India. Possibility of immunodiagnosis of apple stem grooving virus has been explored by Vipin Hallan using polyclonal antibodies.

In this issue, three new reports have been included. First one is the gastroid fungus isolated from the dry areas of Thar Desert of India, the second on Pseudomonas sp. causing bacterial leaf spot on Convolvulus arvensis and the third one is the detection of Candidatus Phytoplasma cynodontis from Napier grass white leaf disease in India.

The editorial team along with the executive council of Indian Phytopathological Society and business manager have been making every effort to bring out the journal on time. Their sincere help is profoundly acknowledged.

Dr. M. Anandaraj

Chief Editor, Indian Phytopathology

Publisher's Note Springer Nature remains neutral with regard to jurisdictional claims in published maps and institutional affiliations.
M. Anandaraj

arajiisr@gmail.com

1 Indian Phytopathological Society, New Delhi, India 